\title{
Socio-economic Implications of the COVID-19 for Smallholder Livelihoods in Zimbabwe
}

\author{
David Mhlanga (PhD) \\ The University of Johannesburg. P. O. Box 524, Auckland Park 2006, South Africa \\ Department of Accountancy \\ dmhlanga67@gmail.com \\ Emmanuel Ndhlovu ( $\mathrm{PhD}$ candidate) \\ University of South Africa, P.O. Box 392, Pretoria 0003, South Africa. \\ Department of Development Studies \\ matahemanu@yahoo.co.uk
}

\begin{abstract}
The article revisits previous viruses such as Ebola to extrapolate the socio-economic implications of the COVID-19. Using secondary sources and the Sustainable Livelihoods Framework (SLF) to guide understanding, the article argues that unless measures are put in place to safeguard smallholder activities in Zimbabwe, COVID-19 has the potential to reproduce the same catastrophic implications created by Ebola in West African countries where peasant food systems where shattered and livelihoods strategies maimed. With a perceptible withdrawal of the government from small-scale farming towards large-scale capital intensive operations, smallholders could now be even more vulnerable. The article concludes that social assistance should now be intensified to protect its vulnerable population from the ravages of COVID-19.
\end{abstract}

Keywords: COVID-19, livelihoods, smallholders, Zimbabwe

\section{INTRODUCTION}

In late December 2019, COVID-19, commonly known as the Coronavirus was identified in China as the main cause of recent human respiratory health cases. The virus was first detected in the Wuhan City, and in a space of months, it had covered the entire globe (Wang and Wang 2020). There are yet no therapeutics and vaccines available. The virus has engendered huge drastic changes to world healthcare, economic, transportation, and education systems around the world. The World Health Organisation on 30 January 2020 declared the virus an emergence World Health Organisation 2020). As of 26 March 2020, a total of 475.170 cases with 21.358 deaths have been recorded worldwide (Worldometer 2020) While the virus is a public health catastrophe, concerns arise on its possible implications for both local and global food systems and their capacity to guarantee safe and affordable food accessibility and utilisation as well as adequate incomes for those located particularly in the smallholder sector of developing countries. Zimbabwe is one of the countries whose household-level food system is sustained by the activities of subsistence smallholders (Mazwi and Mudimu 2020). The COVID-19 comes at a time when Zimbabwe's health system is already in shambles and may not be able to contain the challenge. It would be terrible to imagine the gravity of the virus should it explode in the country as is the case in neighbouring South Africa where about 4 million Zimbabweans live with about 3 million of them working in that country (Chiumia 2019; United Nations 2020). Zimbabwe smallholders had already been under siege by the 'new dispensation' neoliberal regime which, despite the socio-economic challenges which the country faces, has 
targeted smallholders to prove they're worthy for Fast Track Land Reform Programme (FTLRP) acquired land through effective utilisation and production (Elich 2020; Mazwi, Tekwa, Chambati, and Mudimu 2018). They are already a vulnerable category.

Of importance is to note that the consequences of the COVID-19 and the concomitant responses by national governments and other actors to the pandemic are likely to harmfully affect the poor and marginalised categories of societies who lack adequate resources and means to leap back after such catastrophic and unpredictable disruptions. Smallholders of most third world countries fit in this category. Zimbabwe smallholders may not only have their production and incomes disrupted, but may also have challenges in accessing food for personal consumption. As noted by Arif Husain, the World Food Programme's Chief Economist, 'Countries with high levels of food insecurity [and high levels of poverty] are generally more vulnerable and less prepared for an epidemic outbreak and would likely see higher mortality rates' (Beltrami 2020). The literature on COVID-19 is only evolving, and there is thus, limited knowledge about the possible impact on the food security and livelihoods of vulnerable categories of society such as subsistence smallholders. Available literature largely focuses on the epidemiology (Poudel, Meng, Wu, Mao, Ye, Wang, Sun, Sylvia, Rozelle, Raat, and Zhou 2020), causes, clinical signs, diagnosis, prevention, and control of the virus (Sheahan, Sims, and Leist 2020; Poudel, Meng, Wu, Mao, Ye, Wang, Sun, Sylvia, Rozelle, Raat, and Zhou 2020). In Zimbabwe, about 47 per cent of the population is reported to be undernourished (Vhumbunu 2019). Poverty levels are oscillating around 70 per cent (IOL News 2016). When analysed from the International Poverty Line of US\$1.90 PPP, by 2018, about 74 per cent of the total population was classified as poor (World Bank 2019). A study on the possible implications of the COVID-19 for smallholder food security and livelihoods is thus, required.

However, as the COVID-19 virus is still evolving, to ascertain its exact impact may only be speculative. An assessment of its impact on Zimbabwe smallholders could, therefore, be premature as the consequences could depend on the gravity of the pandemic in the country, its duration, the measures which the government could adopt, the intervention of international actors in dealing with the challenge as well as the resilience of the smallholders themselves. However, considering the vulnerability of smallholders (socio-economic and political) who make the majority of farmers in the country, it is vital to forecast how the COVID-19 could impact them to make recommendations. While there is not yet concrete empirical data to base conclusions on, we posit that other global pandemics such as Ebola, Severe Acute Respiratory Syndrome (SARS), and Middle East Respiratory Syndrome (MERS) all had severe implications on food security and livelihoods for vulnerable groups including smallholders, and therefore can be used to extrapolate the consequences of COVID-19 for smallholder livelihoods. For instance, when Ebola-hit Liberia, Guinea, and Sierra Leon in 2014, prices for domestic rice soared by 30 per cent, while cassava price (a staple for Liberia) soared by 150 per cent (FAO 2014; World Bank 2014). In Sierra Leone, the Ebola epidemic and the response strategies used by the state and individuals disrupted the food chain thereby leading to food security and livelihood challenges (UNDP 2014).

The UNDP Regional Bureau for Africa (2014) also reveals that as government policies restricted the movement of people through road blockages and community quarantines in West Africa as a response to Ebola, markets were disrupted, leading to food shortages, and higher prices, especially on stable foods. This directly impacted on the livelihoods and food statuses of the peasantry in particular. In China, the emergence of SARS resulted in food challenges in the cities of Guangdong and Zhejiang (Chen 2020). Currently, due to COVID-19, online 
surveys indicate that the poultry industry is already under stress due to insufficient feed supply and disruptions in marketing (Brodzicki 2020). If the virus persists, it could create food supply hitches and a threat to food security for vulnerable groups (Ou, Wu, Yang, Tan, Zhang, and Gu 2020). Restrictions on transportation and people movement have also led to some food logistics challenges (Beltrami 2020). The production of wheat, rice, and vegetables (staple food crops) could be affected if the pandemic extends into the critical spring planting period as it is currently uncertain whether agricultural inputs can be distributed in time for spring planting. In 2014, the Ebola epidemic resulted in huge sizes of abandoned agricultural lands and reduced fertiliser use in West Africa (FAO 2014). If staple food production is affected, the impact on food security could be serious especially for smallholders to whom agricultural activities are a major source of livelihoods and income. The past experiences, therefore, provide us with important lessons on how we can extrapolate the consequences of COVID-19 and possibly mitigate the impact.

Unlike most Southern Africa countries, Zimbabwe only started recording COVID-19 cases on March 20, a scenario which critics and opposition politics interpreted as a result of the government's hiding of figures, inadequate testing, and insufficient talent to deal with the virus. However, until then, the country had shown no serious commitment to put in place some measures to curb the spread of the pandemic. There seemed to be a general lack of knowledge about the virus with high profile personalities like the Minister of Defence Oppah Muchnguri telling party supporters in Chinhoyi that 'America and her allies [were] being punished by God with the coronavirus' (Okello 2020). As of 27 March 2020, the virus has claimed one life with eight cases recorded across the country (MoHCC, 2020). Several within-reach measures have since been put in place including a national three-week lockdown which started on March 30 . Zimbabwe is operating under difficult times. The pandemic emerges at a time when the sanctions imposed by the Euro-North American powerful countries of the North have shattered the economy and the country's health system. The hardest-hit category has been the smallholder who now struggles to access inputs and markets. The emergence of COVID-19 could represent yet another huge challenge which requires timely research focus to institute anticipatory mechanisms to mitigate its chaotic consequences. Since there is not yet enough literature and empirical evidence to back up arguments, we draw on the implications of other viruses such as the Ebola to conclude the potential impact of COVID-19 for the vulnerable smallholders in Zimbabwe. The article seeks to answer the questions: What could be the livelihoods implications of COVID-19 for smallholders in Zimbabwe? What could be the future trajectory of smallholder livelihoods in the face of COVID-19 in Zimbabwe?

The next sections present the Sustainable Livelihood Framework (SLF) as the theory guiding analysis. This is followed by a literature review and a conceptualisation of smallholders in Zimbabwe, and the research methodology, and a discussion on the implications of COVID19 on smallholder food security and livelihoods. Lastly, the article makes conclusions and recommendations.

\section{SUSTAINABLE LIVELIHOOD FRAMEWORK}

The SLF is widely associated with Chambers and Conway (1992) who define the framework as referring to the capability of a scheme to nourish its levels of production irrespective of the magnitude of disruption experienced. Concepts such as resilience - the ability of communities (smallholders) to survive with external social, political and environmental change stresses and disturbances, and thus, preserve a certain level of well-being (Bennett 2010). The SLF 
combines the crucial aspects that impact on the exposure or potency of the individual or household endurance tactics to encourage the connections of a variety of livelihoods aspects so that those concerned can benefit from the combination and the rapport of livelihoods aspects. In this article, such aspects could include the assets owned by smallholders, the activities they engage in to sustain a tolerable living standard and meet other goals such as risk reduction. The aspects also include the factors that succour or impede smallholders from accessing assets and activities. It was in this view that Chambers and Conway (1992:7) defined a livelihood as '...the capabilities, assets (stores, resources, claims and access) and activities required for a means of living.' Livelihoods come in many different forms and shapes, and they are a crucial means of enabling people to survive. Thus, Chambers and Conway (1992:8) add that 'a livelihood is sustainable which can cope with and recover from stress and shocks, maintain and enhance its capabilities and assets, and provide sustainable livelihood opportunities for the next generation; and which contributes net benefits to other livelihoods at local and global levels in the long and short term.'

Smallholders rely on a variety of both on-farm and off-farm activities to sustain themselves (Ndhlovu 2018). The various activities adopted by these smallholders depend on the obtainability of the five capital assets, namely;

- Human capital: This includes smallholder knowledge on local agricultural production, education (formal and informal), available human labour, the health of household members to contribute labour, etc.

- Natural capital: Accessibility to natural goods such as the land, quality soils, health and sufficient water bodies (for irrigation), and adequate rains since most smallholders practise rain-fed agriculture.

- Financial capital: This includes smallholder savings, credit and loan acquisition opportunities, remittances, pensions etc. which they can use to support their farm activities.

- Physical capital: Availability of tangible farm assets and infrastructure (farms equipment, livestock for draught power; transport and communication networks, etc.).

- Social capital: Smallholder social resources (social, political, and religious networks; local cooperatives; access to agriculture and research institutions, etc.).

The SLF affords us to better understand the importance of subsistence agricultural production for smallholders. Bennett (2010) considers land and rangelands as the most important natural assets that enable smallholders to sustain their food reserves and livelihoods. Smallholders can produce various food crops on land for personal consumption and sale while rangelands can provide goods and services that can be sold or directly consumed (Ndhlovu 2019). In the face of sudden shocks like COVID-19, the SLF proposes several potential interventions meant to sustain livelihoods. These could include the provision of basic social services, such as protective clothing (masks and gloves); knowledge campaigns through pamphlets distribution; implementation of policies (local and national) meant to strengthen the human capital base which is the target of COVID-19. The SLF posits that for the livelihood to be sustainable, it has to be able to sustain or advance the people's standards of living (in terms of satisfaction), decrease exposure to disturbances (COVID-19), and ensure that activities do not jeopardise the human capital. 


\section{LITERATURE REVIEW}

According to Sansa (2020:2), COVID-19 is 'the 2019 novel coronavirus...severe acute respiratory syndrome coronavirus-2 (SARS-CoV-2) while the disease associated with it is referred to as COVID-19.' SARS-CoV-2 was first identified in China at the end of 2019. There is a huge consensus by scholars and policy institutions that the COVID-19 will have huge implications on the future trajectory of healthcare, transport, and education systems (Beltrami 2020; Elham 2020; Sihlobo 2020). However, when it comes to the implications of the virus for global food security and livelihoods, divergent views emerge. Scholars such as Sihlobo (2020) posit that the virus is not likely to alter food systems, at least in South Africa. He argues that South Africa is an agriculturally gifted country and a net exporter of agricultural and food products. Also, the country expected a good harvest of staple grains and fruits in 2020, and thus, it is unlikely to be put at risk by the virus. This view was also supported by Ms Thoko Didiza who is the Minister of Agriculture, Land Reform and Rural Development in South Africa who stated that while several businesses would be affected by COVID-19 and the country's 21-day lockdown meant to flatten the transmission curve, '...the agriculture and food supply sector is one of the essential systems for livelihood and therefore [would] remain operational' (Government of South Africa 2020).

Didiza also added that 'Our food supply system will remain functional during this period. Agricultural production in all its forms will remain uncompromised. This includes all services including provision of veterinary and advisory services' (Government of South Africa 2020). In the context of China, Chen (2020) posits that the virus has not only affected the agriculture sector, but also the broader economy as production has been affected by a manpower crunch due to sickness, fear, and movements restrictions. While the pandemic has been largely contained in China where new confirmed cases are falling rapidly, the challenge of fully restoring logistical operations of agricultural and food supply chains remain. Thus, COVID-19 could remain food and livelihood challenges in China for some time (Chen, 2020).

On a global scale, Beltrami (2020) states that while the food and agricultural sector were supposed to be less affected by the pandemic than other sectors, the illness-related labour shortages, transport disruptions, quarantine procedures restricting activities on farms, as well as access to markets and supply chain will engender food insecurity. This is supported by Danley (2020) who posits that as companies across all sectors, including agriculture, are banning travel for workers and instituting work-from-home programs, a challenge emerges for farmers and their workers who need to be on the fields to produce. However, the International Food Policy Research Institute (2020) is of the view that the virus cannot pose food security challenges since there are adequate stores of staple grains.

On the side of demand, a loss of purchasing power due to the disease could alter eating patterns, leading to poorer nutrition. In countries such as the United States, South Africa, and many others, panic food purchases following the announcement of restriction of movements could disrupt the supply chain and cause localised price hikes (Chen 2020; Nkanjeni 2020). In developed countries such as the United States, it is argued that farmers growing more specialised crops could be affected more than others, and therefore, there is likely to be no significant food security challenges and livelihoods disruptions as farmers who grow these crops are usually well-resourced and do not operate at subsistence level (Poppick 2020). It is also reported that these farmers can easily operate with little interruption as most of them those who grow grain crops use mechanised tools that already reduce human-to-human contact and fall within the guidelines for limiting the transmission of the virus (Charles 2020). 
For poorer African countries, Husain is worried that COVID-19 could produce disastrous effects for the majority of people located in developing countries more than the disease itself. He drew policy attention to the '...poor people in many countries who rely on imports for their food and fuel needs and exports of primary commodities to pay for them. For them, COVID-19 triggered global economic recession will mean a lot more expensive imports and a lot less money through exports (Beltrami 2020). In India where smallholders reported that hunger could kill them before the virus, (Agarwal 2020) due to the lockdown on March 22, the Poultry Site, a knowledge-sharing platform with premium news, analysis and resources for the global poultry industry reveals that with 1.3 billion people relying on agriculture for their livelihoods, COVID-19 has affected the prices of crops such as soya beans, corn, cotton, and onion, thereby putting not only incomes in danger but also livelihoods and prospects for production (The Poultry Site 2020). Nkanjeni (2020) states that in Africa, panic, restrictions, and risk aversion behaviours could result in employment dropouts, income loss, and eventually impacting the purchasing power of households. This could result in many households having difficulties meeting food needs as 70 per cent of households in Southern Africa, for instance, depend on subsistence agricultural activities (Moyo 2016). This could also reduce the number of meals and portion size of meals.

Given the above discussion, it can be concluded that reviewed literature agree that it is too early to predict the possible impact of the COVID-19 for the food status and livelihoods of people and the economic outcomes of countries. As argued by Hall (2020), how countries react to the challenge will define the nature of implications for livelihoods resilience and food security. Without ample groundwork, response strategies, and resources, second-order impacts on the economy, food security, livelihoods, and more will be worsened by non-data-driven and possibly inept policy responses. This indicates that comprehensive food security and agricultural policies are imperative for countries and their vulnerable populations to be able to respond to virus outbreaks and the food security and livelihoods shock they throw up. Altogether, reviewed literature indicates that the emergence of COVID-19 and the resultant restrictions of movement of good and people, and closure of companies, etc. could have severe implications for the poor majorities of developing countries particularly Africa. Smallholders, in particular, could have their already fragile livelihoods strategies being hugely affected.

The article focuses on smallholders who received land under the FTLRP of the 2000s in Zimbabwe. The programme was executed by the government to correct a racially-biased landownership pattern which had been inherited at independence in 1980 where fewer than 6000 white farmers owned 51 per cent of all the total prime land while blacks, who made the majority, languished in marginal agro-ecological rural areas (Muchetu 2018). By 2010, the programme had benefited about 150,000 A1 smallholders (small-sized) operating alongside 20,000 middle-to-large-scale A2 farmers (small-medium-sized) as well as 250 large-scale farms and agro-industrial estates (Moyo 2016). The programme aimed to broaden smallholder participation in agricultural commodity markets, boost their social reproduction, and thus, contribute towards an expanded formal economy which goes beyond the sectional whitedominated large-scale commercial farm sector (AIAS 2014).

There are two strands of smallholders who benefited under the FTLRP. The first is comprised of market-oriented individuals. These combine either paid employment in the formal sector, engage in small businesses in the informal sector or pursue careers in politics. They somehow have some resources that can be ploughed back into farm activities. Some of these smallholders make use of specialised farming technologies and inputs; and thus, are very 
much productive. The other strand, which is the focus of this article, comprises of subsistence producers. Agricultural activities their main source of food, albeit, the surplus is sold for income. They are also an important producer of food to other underperforming smallholders, to communal areas households in their proximity, and to vendors and other individuals who regularly come on the farm to get products. Surplus may be sold some small fruit and vegetable outlets in various locations: bus terminuses, taxi ranks, and by the roadside. Some smallholders engage in cross-border trading. The nature of the second strand of smallholders makes it very vulnerable to sudden shocks, and thus, it is vital to anticipate how the COVID-19 could impact on their food status and livelihood strategies.

\section{RESEARCH METHODOLOGY}

This article is based on the review of secondary data sources; mainly newspaper articles. It also benefits from a few journals, some policy reports, as well as reports from national and international organisations. It was as we engaged with these texts and reports as African citizens that the arguments presented here formulated in our minds. Since COVID-19 literature is only evolving, we refer to the Ebola virus and its implications on food security to extrapolate the implications of the COVID-19 for smallholders in Zimbabwe. We are, however, cognisant that these viruses differ greatly in terms of genetics transmission pathways, and severity, and also that Zimbabwe has had no Ebola cases. The discussion of possible implications is structured according to the five capitals of the SLF. The conceptual nature of the article presents a particular limitation, albeit, we hope that other researchers will be inspired to critique and problematise the arguments made here through empirical evidence.

\section{DISCUSSION ON IMPLICATIONS ON SMALLHOLDER LIVELIHOODS}

The extrapolation of the possible implications of COVID-19 is discussed in five sub-sections which mirror the five asset capitals of the SLF.

\section{Human capital}

Human capital would include the safety of smallholder members from COVID-19 infections to continue farm operations. COVID-19 is a stranded ribonucleic acid virus that can infect farmers and their members leading to death (Pouldel et al. 2020). All its signs and symptoms (fever, cough, dyspnea, myalgia, fatigue, sore throat, and severe pneumonia, etc.) could hamper the work performance of infected individuals on farms where strong and healthy labour is needed for ploughing, wedding, chemical spraying, and harvesting. With smallholders highly depending on household labour in Zimbabwe and with no capacity to hire waged-labour, the infection of household members has the potential to disrupt farm activities which could lead to food insecurity and stunted livelihoods. In a qualitative study by the Ministry of Agriculture, Forestry and Food Security in 2014 in Sierra Leone, it was found that 61 per cent of the smallholders indicated that the production levels on the farm had dropped due to sickness and death due to Ebola as compared to last year (Republic of Sierra Leone 2014). The study also revealed that the virus had generally affected agricultural production, markets operation, and the general food security for both the rural and urban communities. The same was reported in Liberia where smallholder production and fisheries plummeted thereby plunging rural dwellers in a livelihoods crunch and a food crisis with severe and long-lasting impacts on the livelihoods of smallholders and fishermen (UNDP-RBA 2014).

The major population category most affected by Ebola was those between 15-45 years in three of the most affected countries, namely; Sierra Leone, Liberia, and Guinea (Bower, 
Johnson, Bangura, Kamara, Kamara, Mansaray, Sesay, Turay, Checchi, and Glynn 2016). Children and the elderly were spared to some extent (Helleringer, Noymer, Clark, and McCormick 2016). The male population was the most affected by Ebola (Brainard, Hooper, Pond, Edmunds, and Hunter 2016). Farming is a labour-intensive activity, and thus, requires the participation of the strong and dynamic. The slaughter or sickness of the younger section of societies, and of younger males in particular who are most dynamic, and most productive, and whose vital labour is crucial for agricultural production affected both farm production and livelihoods. The death and sickness of young males would increase both child labour and unwaged female labour to subsidise the social reproduction of affected male labour-power, thereby disrupting, not only livelihoods and the food status, but also the wider rural economy. The COVID-19 however, is affecting all categories of society although different age groups have different risks of getting severe symptoms that require hospitalisation or intensive care. The chances of deaths also vary across age groups with kids and young adults likely to be fine, but the risk is more severe for the elderly with the 80 years and above category contributing 20 per cent of the total deaths (European Centre for Disease Prevention and Control 2020). However, what we know as of March 30 is that of all the cases across the world, about 14.3 per cent of the infected are young adults to adults (20-44 years) (Scott 2020). In Zimbabwe, all the first eight cases were of those under 44 years of age, the youngest being the journalist Zororo Makamba who was 30 years old (MoHCC 2020).

Given both global and national trends, COVID-19 has the potential to reproduce the same catastrophic implications for Zimbabwe smallholders unless if measures are put in place to safeguard crop production activities. It could disrupt gender balances which are already fragile due to rural-urban migration in resettled Zimbabwe (Ndhlovu 2019). The slaughter of the elderly by the virus could render smallholders vulnerable to the emerging the neoliberal regime in Zimbabwe which increasingly requires smallholders to demonstrate they're worthy through production or else lose the land to others, most likely foreign investors. The government is also pro-capital with the government's Transitional Stabilization Program published on 05 October 2018 detailing that among the reforms to be implemented within the next two years was to ensure that the agriculture sector would be '...inevitably be driven by the private sector.' This would entail 'opening the country to international investors and financiers' and also creating 'an enabling environment for state and non-state actors, including the private sector and communities in the delivery of public goods and services, and development' (Mnangagwa 2020). Should increases in COVID-19 cases obtain in the countryside, plummeting production will be witnessed much to the accelerated land grabs from smallholders by the neoliberal regime.

There is huge evidence which shows that most of the FTLRP beneficiaries were war veterans, although some sections of the population also benefited (Masiiwa and Chipungu 2004; Njaya 2014). These have been very active in ensuring ZANU-PF's continued ascendency to power. Most of these people are over 60 years old today and are, therefore, vulnerable to the extreme consequences of the virus. Should there be deaths, their land offers could be withdrawn in favour of finance capital thereby leaving their families vulnerable as detailed under the natural capital sub-section. Where sicknesses obtain, productive time and resources by other household members will also be spent towards the health of the infected.

Most importantly the most critical threat of COVID-19 is its impact on the health of women. The United Nations Conference on Trade and Development (UNCTAD), it is estimated that 70 per cent of the food produced in Africa is directly produced by women. In various countries in southern African particularly Zimbabwe, rural women are the primary food crop producers while on the other hand men are more involved in animal husbandry or off the farm labour. The worrying aspect is that women are mostly responsible for the care of children, the sick and elderly (UNCTAD 2020). This implies that they could be exposed to the virus 
contract which will have a direct impact on the production of food and food preparation and child nutrition. The end result will be low levels of output produced in the farms affecting food security.

\section{Financial capital}

This includes smallholder savings, credit, and loan acquisition opportunities, remittances, pensions etc. which they can use to support their farm activities. Livestock and flocks are also a form of savings in Zimbabwe (Ndhlovu 2018). Because of the economic challenges which Zimbabwe currently faces, there has also been a huge rural-urban and cross border migration. In areas such as the Sangwe farm in Chiredzi, where almost every smallholder household had an average of members who had migrated either in towns or out of the country South Africa (Vhumbunu 2019). These generated remittances which would be used as a strategy to expand the financial capital and invest in new livelihood strategies on the farm. Migration enabled smallholders to acquire inputs (fertilizer, seeds and chemicals), farming technologies as well as to pay for extra labour needed for land cultivation, weeding, harvesting and for looking after livestock of the farm and hence keep their livelihoods intact. Also, the cash was used to meet other household basic needs (education, clothing, housing and medication); paying lobola, circumcision and for transport.

However, COVID-19, just like Ebola and SARS, directly affects people. Its effects range from mild to extreme sickness and death (Beltrami 2020; Elham 2020). This results in households having to use their meagre savings, loans, and remittances to pay for the hospitalization of sick members. These effects go beyond economic implications and health, in terms of morbidity and mortality, but it also affects livelihoods. In Liberia, the disruption and strain of household financial capitals as families responded to the effects of Ebola rendered their food security highly susceptible to financial capital shocks as they had little buffer when their purchasing power was eroded (FAO 2014). The eruption of the Ebola crisis, particularly the behavioural modifications in the West Africa population, has had serious impacts on the livelihoods of households (Republic of Sierra Leone 2014). COVID-19 being also a virus, and with the Zimbabwe smallholders being located within similar circumstances of collapsing health care systems and increasing poverty as in West Africa, the virus could have huge negative implications across the various categories of smallholder capitals. With poverty levels on the increase in recent years, COVID-19 could put unbearable pressure of the peasantry. If analysed from the International Poverty Line of US\$1.90 PPP, about 74 per cent of the total population was classified as poor in 2018 (WB 2019). With basically no financial reserves through credit or loan facilities due to economic meltdowns and inflation which stood at 540.2 per cent in January 2020 (Trading Economics 2020), as well as the collapse of the banking sector in the country, COVID-19 could place many smallholders at risk of sinking deeper into abject poverty.

\section{Natural capital}

The natural capital includes accessibility to natural goods such as the land, quality soils, quality and sufficient water bodies (for livestock and flocks), and adequate rains since most smallholders practise rain-fed agriculture. On its arrival in November 2017 through a 'soft coup' that topped Robert Mugabe, the 'new dispensation' government affirmed that the FTLRP would not be reversed. However, it has since then required beneficiaries to demonstrate their worth by producing tangible results. Land audits are also in progress to authenticate the 
deservedness of beneficiaries with the aim of either downsizing the land owned by underperformers or ensuring that they surrender the land to more productive farmers (Mazwi et al. 2018). This comes when a nationwide survey by the African Institute of Agrarian Studies revealed high rates of land underutilisation by FTLRP beneficiaries of below 20 per cent across all models (small-sized, medium-sized and communal areas) (AIAS 2014) due to inputs and equipment, agro-ecological, and many other challenges. In a country where public health systems have collapsed due to socio-economic and political challenges, COVID-19 reproduces huge negative implications for smallholders who will have to use their only little resources (personal savings and livestock) to access health care in the private sector. The only natural resources which they cannot dispose of is their land since it remains state property with some farmers still waiting for offer letters (Ndhlovu 2017).

The diversion of resources from farm activities towards health access could justify smallholder land displacement by the neoliberal regime that will blame them for land underutilisation. COVID-19 will, therefore, not only disrupt, disfigure, and shatter down smallholder livelihoods, but it could also expose them to the land grabs tendencies of the neoliberalism regime and capital. Unlike the Mugabe regime which promoted inward-looking policies and only reached out to the east under the 'Look East Policy' when the need arose, the Mnangagwa regime is pro-capital and seeks to reach out to the Euro-North American countries and their Bretton Woods Institutions. The need to appease these capitalist countries has seen the displacement of the peasantry. Mazwi and Mudimu (2019) report that this tendency has seen either the eviction or the threat thereof of more than 30,000 peasants to accommodate Euro-American, but also Chinese-based mining operations, and agribusiness operations, or for occupation by finance capital. With resources having been spent to pay for the health or funeral arrangements of household members slaughtered by COVID-19, farmers could be cornered to engage in unbalanced and exploitative 'joint ventures' with former white commercial farmers. While balanced joint ventures can close the gaps in agricultural financing and also boost agricultural production in the countryside, smallholders could lose land control and to their partners who could manipulate production processes towards non-foods (Mazwi et al 2018). COVID-19 in Zimbabwe could thus result in land separation and concentration by monopolistic capital supported by the state thereby compromising not only livelihoods but also smallholders to whom agriculture is the major source of income.

\section{Physical capital}

Farm assets (farms equipment and livestock for draught power) and infrastructure (transport and communication networks, etc.) constitute the physical capital of smallholders. The sale of assets and livestock to get cash to access medication during the COVID-19 pandemic represents a huge shock from which smallholders will have a challenge in crawling back. Considering the limited number of farm equipment and livestock in most resettled areas in Zimbabwe (Mudefi 2011; Paulo 2004), the sale of these assets will not only undermine agricultural operations and food systems, but it will also strain livelihood strategies, and further create more conducive conditions for underperformance. This will then create a cycle of challenges as the farmers will be blamed for underperformance and be forced to either engage in joint ventures or relinquish land to more productive candidates, most likely foreign-based investors. Where this happens, the FTLRP would have failed its aims to ensure household livelihood development through farming. 
Smallholders also engage in trade both domestic and international. In domestic trade, smallholder farmers engage in petty trade whereby they sell the surplus to some small fruit and vegetable outlets in various locations: bus terminuses, taxi ranks, and by the roadside while some even engage in cross-border trading (Ndhlovu 2019). In times of crisis like the COVID19 where hard cash is needed for accessing medication, petty trade becomes an important smallholder activity. Petty trading is a way of earning money with the sale of small inexpensive items obtainable on the farm and rangelands. However, the movement measures that have come with COVID-19 have petty trade. The national lockdowns in many Southern Africa countries and the infection aversion measures put into place by governments, both local and national, have caused petty trading to decline. The closure of roads across the country in response to COVID-19 could further constrain smallholder livelihoods development. Some regulation heavily prohibits domestic trade. For instance, in Zimbabwe, the Herald state newspaper reported that on April 3, 2020, smallholder farmers who were selling their wares in the Mutare, Sakubva vegetable market in Manicaland province had their agricultural products confiscated by the government and destroyed as part COVID-19 aversion and lockdown measures.

Catastrophic consequences were also reported when Ebola-hit West Africa when the customer base for smallholder petty traders dramatically plummeted (FAO 2014). The FAO also reported that almost all livelihood capitals were impacted by the Ebola-induced market changes in Liberia - particularly the result of government measures to reduce the risk of Ebola transmission. Quarantines, roadblocks, and the shutting down of markets almost universally inflated market prices, led to a reduction in the quantities of some market items, and also led to a significant decrease in the number of customers for farmers and the volumes they purchased, due to serious declines in purchasing power (FAO 2014). Thus, the impact of COVID-19 on the road network could not only create a situation where infected people do not get access to hospitalization but also constrain them from engaging in activities that can ensure food availability within households. This will further negatively impact on all the other categories of livelihood capitals required for productive farming in resettled areas.

Apart from domestic trade, international trade is also another aspect that is affected and if proper measures are not taken, the future of trade will be affected. The World Trade Organisation (2020) states that the 'COVID-19 pandemic represents an unprecedented disruption to the global economy and world trade, as production and consumption are scaled back across the globe.' The major risk associated with COVID-19 is that, in countries where health systems are not functional and where strong measures to reduce this pandemic are taken. If care is not taken, the pandemic can create long term threat on trade. For instance, products from countries where COVID-19 is not dealt with adequately, will not find their way to other countries as these countries will not be able to accept the products in fear of the pandemic. This will have a strong impact on smallholder farmers in Zimbabwe where there is no clarity on the measures which are being taken to combat this virus. Apart from its effects on exports of smallholders, COVID-19 will have a huge impact on the imports especially the prices of inputs. In countries like Zimbabwe where farmers depend more on the inputs from other countries, COVID-19 will have a huge impact on the cost of imported inputs, and therefore, production. The UNCTAD (2020) also reported that many African countries are net importers of food, with the continent spending about $\$ 65$ billion on food imports in 2017 . Though there is no documented evidence of COVID-19 on food imports, its existence is presenting a threat in this direction. 
UNCTAD (2020) went on to insinuate that the fact that 'China has become the central manufacturing hub of many global business operations, any disruption of China's output is expected to have repercussions elsewhere through regional and global value chains.' Also, the recent data from China indicated that output declined drastically. The China manufacturing purchasing index (PMI) fell by 22 points in February (UNCTAD 2020; Sansa, 2020). It is generally believed that this index is highly correlated to exports. As a result, a fall in this index implies a fall in exports of about 2 per cent on an annualised basis (Sansa 2020). This shows that smallholders with a bias on imported inputs will heavily pay the price.

\section{Social capital}

It can never be overemphasised that when trying to analyse the circumstances of resettled smallholders, their social capital, that is, their social resources (social, political, and religious networks; local cooperatives; access to agriculture and research institutions, etc.) should always be prioritised. Thus, when analysing the impact of COVID-19 for smallholder livelihoods, it is vital to go beyond production and protection aspects, and also understand the possibility for social disruption by the virus. Social cohesion and cooperation for smallholders could be more vital than the acquired land itself. Although social cohesion is multi-faceted, it can be compressed into four main categories, namely; social, task relations, perceived utility, as well as emotion. Burns, Hull, Lefko-Everett, and Njozela (2018:10) define social cohesion as '...the extent to which people are co-operative, within and across group boundaries, without coercion or purely self-interested motivation.'

COVID-19 is a highly contagious virus and it spreads through human-to-human transmission. To deal with it, people need to 'social distance' themselves (Beltrami 2020; Brodzicki 2020). The instituted lockdowns across the world, including Zimbabwe, are meant to confine the movement of people to flatten its transmission curve. This disrupts the social capital of smallholders as they no longer can work together to boost productivity on the farm and strengthen their livelihoods strategies (Ndhlovu 2018). Social capital in the form of networks (political and communal), cultural norms (formation of cooperatives), and other social attributes are essential in the sharing of knowledge, exchanging of experiences, and cooperation among resettled smallholders (Mkodzongi 2013). Smallholders engage in closecontact activities during ploughing, weeding, and harvesting sessions to make the work easier. They also share farm equipment and other farm services (Ndhlovu 2018). This increases their social protection. The disruption of these networks through lockdowns, quarantines, and restrictions of movement in response to COVID-19 renders smallholders very vulnerable to sustained food agricultural underperformance and disrupted livelihoods. Low production on farms will lead to increased food prices by sellers much to the food insecurity of people. In West Africa, the stigmatisation of entire communities that had Ebola-infected members, quarantines, social distancing, movement restrictions, both for people and goods, and the departure of people from areas that had Ebola incidences - all impeded the ability for smallholders to produce and provide for themselves (FAO 2014; UNDP 2014).

In Zimbabwe where about 72.3 per cent of the total population is classified as poor (IOL News 2016), the provision COVID-19 testing equipment would also need to be supported by safety nets so that smallholders can flexibly respond to the shock. Zimbabwe with its current poverty levels renders the majority of smallholder farmers are food insecure, and thus, more vulnerable and less prepared for an epidemic outbreak. With no external supported across all 
the five capitals of the SLF, COVID-19 would likely see higher mortality rates, not only in the countryside but also in urban areas.

\section{CONCLUSIONS AND RECOMMENDATIONS}

The article investigated the impact of the COVID-19 on the socio-economic implications for smallholder livelihoods in Zimbabwe. The study revisited the previous viruses such as Ebola to extrapolate the socio-economic implications of the COVID-19. Using secondary sources and the SLF to guide understanding, the article argues that unless measures are put in place to safeguard smallholder activities in Zimbabwe, COVID-19 has the potential to reproduce the same catastrophic implications created by Ebola in West Africa countries where peasant food systems where shattered and livelihoods strategies maimed. The extrapolation of the possible implications of COVID-19 was discussed in five sub-sections which mirror the five asset capitals of the SLF, namely; human, financial, natural, physical, and social capitals. The article posits that not only will vulnerable producers such as smallholders experience greater difficulties accessing enough food for survival and adequate nutrition due to COVID-19, but also many individuals and whole communities that rely on them for food production. Food chain shocks by COVID-19 could disrupt flows of production and trade as has already been noted concerning the seizure and destruction of peasant wares by the police in Mutare. This could produce unstable market effects and implications on both food prices and agri-foodbased incomes. Certain economic impacts could continue further than the height of the pandemic. These could include amplified disabilities in human/cognitive growth as a result of extended lean seasons and other caloric deficiencies especially among those who are already food insecure. This could further lead to next-generation reductions in human capital and the ensuing economic impacts.

The article recommends that with the unavoidable impact of COVID-19 on smallholders, the government must increase its support towards smallholders as well as all the vulnerable households that directly depend on the land and agriculture-related activities, both for livelihood development and incomes. First, the government of Zimbabwe should expand the fiscal space by giving massive subsidies to smallholders either in the form of loans or inputs and equipment. This can help in stimulating and sustaining farm operations, and thus, increase the food security of farmers. When smallholders are given the necessary financial support in terms of affordable loans, they can flexibility and resiliently respond to the threats posed by COVID-19. The government should not in any way withdraw support from smallholders towards large-scale capital intensive operations since with an economy battered by sociopolitical factors, the remaining informal smallholder livelihood strategies may now be even more valuable. The article concludes that supporting smallholders as part of policy and development designs can enable Zimbabwe to protect its vulnerable population from the ravages of CIVID-19.

\section{REFERENCES}

African Institute for Agrarian Studies. 2014. Land use, food security and agricultural production survey. Harare: AIAS.

Agarwal, K. 26/03/2020. Hunger can kill us before the virus: Migrant workers on the march during the lockdown. The WIRE. 
Beltrami, S. 2020. How to minimize the impact of coronavirus on food security. The World Food Programme Insight. https://insight.wfp/how-to-minimize-the-impact-of-coronavirus-onfood-security-be2fa7885d7e. (Accessed 26/03/2020).

Bennett, N. 2010. Sustainable livelihoods from theory to conservation practice: An extended annotated bibliography for prospective application of livelihoods thinking in protected area community research. Protected Area and Poverty Reduction Alliance Working Paper No.1.

Brainard, J., Hooper, L., Pond, K., Edmunds, K., and Hunter, P, R. 2016. Risk factors for transmission of Ebola or Marburg virus disease: A systematic review and meta-analysis. Int $\mathbf{J}$ Epidemiol, (45):102-16.

Bower, H., Johnson, S., Bangura, M, S., Kamara, A, J., Kamara, O., Mansaray, S, H., Sesay, D., Turay, C., Checchi, F. and Glynn, R, J. 2016. Exposure-specific and age-specific attack rates for Ebola virus disease in Ebola-affected households, Sierra Leone. Emerging Infectious Diseases, 22(8):1403-1411.

Brodzicki, T. 2020. Impact of COVID-19 on the Chinese and global economy. HIS Markit. https://ihsmarkit.com.research-analysis/impact-of-covid19-on-the-chinese-and -globaleconomy.html. (Accessed 26/03/2020).

Burns, J., Hull, G., Lefko-Everett K and Njozela, L. 2018. Defining social cohesion. Cape Town: SALDRU, UCT. Working Paper 216.

Chambers, R and Conway, G. 1992. Sustainable rural livelihoods: Practical concepts of the $21^{\text {st }}$ Century. Brighton: Institute of development studies.

Charles, D. 18/03/2020. COVID-19 Threatens Food Supply Chain As Farms Worry About Workers Falling Ill, NPR Hour Program Streamon Air.

Chaumba, J., Scoones, I., and Wolmer, W. 2003. From jambanja to planning: The reassertion of technocracy in land reform in south eastern Zimbabwe. Journal of Modern African Studies 41,4 .

Chen, K. 06/03/2020. If coronavirus disrupts staple crop production the impact of food security could be grave. The Telegraph.

Chiumia, S. 2019. How many Zimbabweans live in South Africa? The numbers are unreliable. Africa Check. www.africacheck.org. (Accessed 13/11/2019).

Danley, S. 17/03/2020. Food industry braces for coronavirus impacts. Food Business News.

FAO. 2014. Ebola leaves hundreds of thousands facing hunger in three worst-hit countries. http://www.fao.org/news/ story/en/item/272678/icode/ Accessed (26/03/2020).

Elich, G. 2020 'Mnangagwa’s Neoliberal Assault on the Zimbabwean People'.

CounterPucnh.org, 14 February 2020.

Elham, H, A. 2020. Coronavirus COVID-19. PosterJ 9(1):5-13.

European Centre for Disease Prevention and Control (ECDC). 2020. Novel coronavirus. https://www.ecdc.europa.eu/en/novel-coronavirus-china. (Accessed 17/02/2020).

Glynn, J, R. 2015. Age-specific incidence of Ebola virus disease. Correspondence, 386(9992):432-5. 
Government of South Africa. 2020. Minster Thoko Didiza: Agriculture and food sector of South Africa Coronavirus. Government of South Africa.

Hall, B. Coronavirus and the Implications for Food Systems and Policy. AGRILINKS. (2020). https://www.agrilinks.org/post/coronavirus-and-implications-food-systems-and-policy\&hlen-ZA. (Accessed 26/03/2020).

Helleringer, S., Noymer, A., Clark, S, J, and McCormick, T. 2016. Did Ebola relatively spare children? Lancet, 386(15):1442-3.

International Food Policy Research Institute. 2020. As COVID-19 spreads, no major concern for global food security. IFPRI. www.ifpri.or/blog/covid-19-spreads-no-major-concernglobal-food-security-yet. (Accessed 26/03/2020).

IOL News. 26/09/2016. '70 per cent of Zimbabweans live in poverty. www.iol.co.za/news/africa/70 per cent-of-Zimbabweans-live-in-poverty-2073058. (Accessed 18/10/2019).

Masiiwa, M and Chipungu, L. 2004. 'Land reform programme in Zimbabwe: Disparity between policy design and implementation' in Masiiwa M. (Eds.) Post-independence land reform in Zimbabwe: Controversies and impact in the economy. Harare: University of Zimbabwe.

Mazwi, F and Mudimu, T. G. 2020. Why are zimbabwe's land reforms being reversed? Economic and Political Weekly, 54(35).

Mazwi, F., Tekwa, N., Chambati, W., and Mudimu, G, T. 2018. Locating the Position of Peasants under the 'New Dispensation': A Focus on Land Tenure Issues. Harare: SMAIAS.

Mkodzongi, G. 2013. Fast tracking land reform and rural livelihoods in Mashonaland west province of Zimbabwe: Opportunities and constraints, 2000-2013. The University of Edinburgh ( $\mathrm{PhD}$ thesis).

Mnangagwa, D, E. 2018. 'Preface' Transitional Stabilisation Programme: Reforms Agenda. Zimbabwe Ministry of Finance and Economic Development, October 5, 2018.

MoHCC.2020. Coronavirus (COVID-19) updates 27 March 2020, Ministry of Health and Child Care, http://www.mohcc.gov.zw/

Moyo, S. 2016. Family farming in sub-Saharan Africa: Its contribution to agriculture, food security and rural development. Food and Agriculture Organization of the United Nations and the United Nations Development Programme. Working paper number 150.

Muchetu, R, G. 2018. Agricultural Land-delivery Systems in Zimbabwe: A Review of Four Decades of Sam Moyo's Work on Agricultural Land Markets and Their Constraints. African study monographs: Supplementary issue (57):65-94.

Mudefi, R, A. 2011. Fast track land reform programmes and household food security: the case of Mutare district, Zimbabwe. Pretoria: University of South Africa (Masters Dissertation).

Ndhlovu, E. 2017. An analysis of household livelihoods under the fast track land reform programme in Chiredzi, Zimbabwe (MA dissertation) University of South Africa.

Ndhlovu, E. 2018. Relevance of sustainable livelihood approach in Zimbabwe's land reform programme. Africa Insight, 47(4): 72-87. 
Ndhlovu, E. 2019. The migration-livelihoods nexus: Emerging opportunities, emerging challenges in rural Zimbabwe. Paper presented at the Symposium on 'Food Security, Migration and Innovation in Senegal and Zimbabwe: Lessons for Africa', Dakar, 26-27 June, 2019.

Njaya, T. 2014. Closing Gender Asset Gap in Land Access and Control in A1 Schemes in Zimbabwe. IOSR Journal of Humanities and Social Science, 19(1): 39-51.

Nkanjeni, U. 25/03/2020. 'SA shoppers ignore pleas to stop panic buying and stockpiling.' The Times Live.

Ou, F., Wu, H., Yang, Y., Tan, W., Zhang, J., and Gu, J. 2020. Countermeasures for rapid spread of new coronavirus pneumonia in Wuhan. Chinese General Practicing Nursing. http://kns.cnki.net/kcms/detail/14.1349.R.20200131.1319.002.html. (Accessed 26/03/2020).

Okello, C. 2020. Zimbabwe's Mnangagwa moves to calm 'coronavirus sent from God' controversy, RFI.

Paulo, W. 2004. Land reform in Zimbabwe: A Development Perspective. University of South Africa (MA Dissertation).

Poppick, L. 26/03/2020. The effects of COVID-19 will ripple through food systems. Scientific American.

Poudel, S, A., Meng, S., Wu, Y., Mao, Y., Ye, R., Wang, Q., Sun, C., Sylvia, S., Rozelle, S., Raat, H., and Zhou, H. 2020. A literature review of 2019 Novel Coronavirus during the early outbreak period: Epidemiology, causes, clinical manifestation and diagnosis, prevention and control. Creative Commons, 1-10.

Republic of Sierra Leone. 2014. The Food Security Situation in the context of Ebola Outbreak in Sierra Leone: A Rapid Assessment Report. Ministry of Agriculture, Forestry and Food Security.

Sansa, N, A. 02/03/2020. Analysis for the Impact of the COVID - 19 to the Petrol Price in China. Available at SSRN: https://ssrn.com/abstract=3547413(Accessed 02/04/2020).

Scott, D. 23/03/2020The COVID-19 risks for different age groups, explained. The Vox.

Sheahan, T, P., Sims, A, C., and Leist, S, R. 2020. Comparative therapeutic efficacy of remdesivir and combination lopinavir, ritonavir, and interferon beta against MERS-CoV. Nature Commun, 11(1):2-22.

The Poultry Site. 2020 Coronavirus undermines Indian crop prices, derails rural rebound. The Poultry Site. https://thepoultrysite.com/news/2020/03/coronavirus-undermines-indian-cropprices-derails-rural-rebound\&hl=en-ZA (Accessed 26/03/2020).

Trading Economics. 20/03/2020. 'Zimbabwe inflation rate.' http://tradingeconomics.com/zimbabwe/inflatin-cpi. (Accessed 31/03/2020).

United Nations. 2020. World Population Prospects: The 2017 Revision. United Nations Department of Economic and Social Affairs.

UNCTAD.2020. Monitoring the effects of the global pandemic on manufacturing, trade, foreign direct investment and economic growth. Coronavirus (COVID-19): News, Analysis and Resources https://unctad.org/en/Pages/coronavirus.aspx

UNDP. 2014. National Study on the Socio-economic Impacts of the Epidemic of Ebola Virus Disease in Sierra Leone, A Draft Report, UNDP Sierra Leone. 
UNDP Regional Bureau for Africa. 2014. Livelihoods are threatened in Guinea, Liberia and Sierra Leone by Ebola Virus Disease. United Nations Development Programme Africa Policy Note, 1(5): 28. 